\title{
妊娠・授乳がマウス下影骨の骨密度に及ぼす影響
}

\author{
篠原淳・正橋 鉄 夫 $^{*}$ 風岡宜 暁 $\cdot$ 川瀬哲人 \\ 久野一森篤志・加藤康弘 $\cdot$ 山田史郎
}

\section{Changes in mandibular bone mineral density during pregnancy and lactation in mice}

\author{
Atsushi Shinohara - Tetsuo Masahashi * Y Yoshiaki Kazaoka - Tetsuhito Kawase \\ Hajime Kuno $\cdot$ Atsushi Mori $\cdot$ Yasuhiro Kato $\cdot$ Shiro Yamada
}

\begin{abstract}
We studied the changes in mandibular bone mineral density (M-BMD) associated with pregnancy and lactation in mice.

Methods

Five female ddy mice were used in each of the following groups: control groups consisting of non-pregnant mice $8,11,14,17$ weeks old; pregnant, non-lactating groups consisting of 8 -week-old pre-pregnant mice, 11-week old post partum mice, and 14- and 17-week-old puerperal, non-lactating mice; and pregnant, lactating groups, used to investigate the effect of lactation on M-BMD, consisting of 11-week-old post partum mice, and 14-and 17-week-old puerperal, lactating mice (both groups lactating for 3 weeks). Portions of the left mandible were resected, and bone mineral content (BMC) was measured by dual-energy $x$-ray absorptiometry (DXA; ultrahigh resolution mode, Hologic QDR 1000). Mandibular area (cm 2 ) was measured with the use of an image analysis program (Ultimage, I\&I). Bone mineral density was obtained from BMC and mandibular area.
\end{abstract}

A factorial ANOVA was used for statistical analysis.

Results

1) There was no difference in M-BMD associated with pregnancy.

2 ) M-BMD was significantly lower in puerperal 14-week-old lactating mice, but this difference rapidly disappeared after lactation was discontinued.

Key words: pregnant (妊娠), lactation (授乳), mandibular bone (下顎骨), DXA (二重エネルギー $\mathrm{X}$ 線吸収測定装置), bone mineral density（骨密度）

緒言

近年, 産婦人科領域では妊娠・産褲期の骨代謝に関 して骨密度, 骨代謝パラメーター, 女性・妊娠関連ホ
ルモンの測定による臨床検討や動物実験がなされてき た ${ }^{111)}$.これらの報告からは, この時期での活発な骨 吸収や骨形成が示唆されており, 骨密度の変動を指摘 する報告もみられる.一方, 骨代謝と顎・只腔領域疾
爱知医科大学附属病院歯科口腔外科

(主任 : 山田史郎助教授)

*愛知医科大学産婦人科講座

(主任 : 中西正美教授)

Department of Oral and Maxillofacial Surgery, Aichi Medical University (Chief: Associate Prof.
Shiro Yamada)

* Department of Obstetrics and Gynecology, Aichi Medical University (Chief: Prof. Masami Nakanishi)

受付日 : 平成 11 年 3 月 26 日 


\begin{tabular}{|c|c|c|c|}
\hline 週 齢 & 対照群 & 非授乳群 & 授乳群 \\
\hline 8 & 非妊娠 & 妊娠前 & \\
\hline 11 & 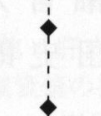 & 出産直後 & 出産直後 \\
\hline 17 & $\vdots$ & 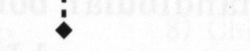 & 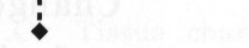 \\
\hline
\end{tabular}

ddy 雌マウス 各群の各週齿 5 匹

図1 群分け

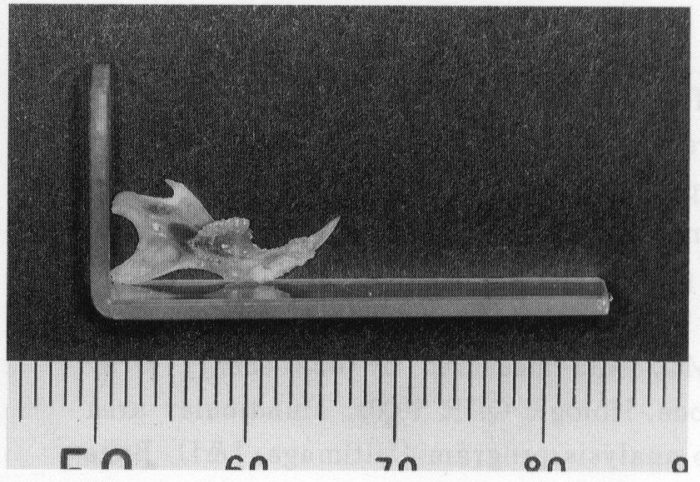

写真 1 ステントによる下顎骨の位置設定

患の関係については骨粗鬆症動物モデルでの下顎頭の 骨梁減少12), 顎骨皮質骨密度と骨梁密度の低下 ${ }^{13)}$ の 確認に続き, 根尖病変拡大 ${ }^{14)}$ の報告があり，また，骨 粗鬆症による骨塩量の低下と顎関節症との関連を示唆 する臨床検討15) がある.

以上の観点からは妊娠 - 産裖期の顎骨においても骨 密度と顎・ 口腔疾患の関連が考えられる.しかし現在 までに妊娠・産裖期の母体の下顎骨骨密度の推移を二 重エネルギー $\mathrm{X}$ 線吸収測定装置を用いて検討した報 告は見られない，そこで今回われわれは妊娠および産 褯期マウスを用いて, 妊娠および授乳が下顎骨骨密度 に与える影響を二重エネルギー $\mathrm{X}$ 線吸収測定装置の 小動物測定モードを用いた計測法 (以下 DXA 法)に より骨密度を測定し, 検討したので報告する。

\section{実 験 方 法}

\section{1. 実験動物および飼育環境}

実験動物として雌の ddy マウスを用い，6 週齢より クリーン conv 環境下 (水: 滅菌水道水. 照明 : $8: 00$ 点 灯, 12 : 00 消灯の 12 時間明暗. 室温 : $23 \pm 1{ }^{\circ} \mathrm{C}$. 湿度 : $50 \pm 15 \%$. 換気 : 26 回/時. 飼育ケージ : オートクレー ブ滅菌.) で飼育を開始し, 飭 (クレア $\mathrm{CE}-7$ ) ・水は 自由摄取とした。

\section{2. 群分け}

マウスは 3 群に分けた. 対照群は非妊娠 8，11，14, 17週齢とし，この群に対して妊娠・出産による影響を 検討する目的で妊娠前 8 週歯, 出産直後11週齢, 出産 後非授乳の14週齢と17週齢からなる非授乳群を設定し た (図 1 ).ささらに非授乳群に対して授乳による影響を 検討するために出産直後11週齢, 出産後 3 週間授乳さ せた14週龄, 出産後 3 週間授乳させた後に断乳した17 週齢からなる授乳群を設定した（図 1 ).なお，各群の 各週齢では 5 匹づつのマウスを体重測定を行った後に 無痛下に薬殺して用いた. また, 非授乳群と授乳群の 仔マウス数には偏りがないことを確認している.

\section{3 . 下顎骨骨密度の測定}

マウス下顎骨骨密度の計測は以下の方法により計測 した。

1 ) 骨塩量の測定

各マウスの左側下顎骨を摘出後, 二重エネルギー $\mathrm{X}$ 線吸収測定装置 (Hologic QDR-1000) を用い小動物 測定モードである Ultrahigh resolusion mode で骨 塩量 (mgrams) の測定をアクリル板使用法でおこなっ た ${ }^{16)}$. 骨塩量の測定時には測定用のステントを使用し， 下頢骨骨体部の最下点と角突起最下点を結ぶ直線（以 下, 直線 A とする) と QDR-1000の放射線の測定経路 が直角になるように位置を設定した（写真 1 , 図 2 ). 


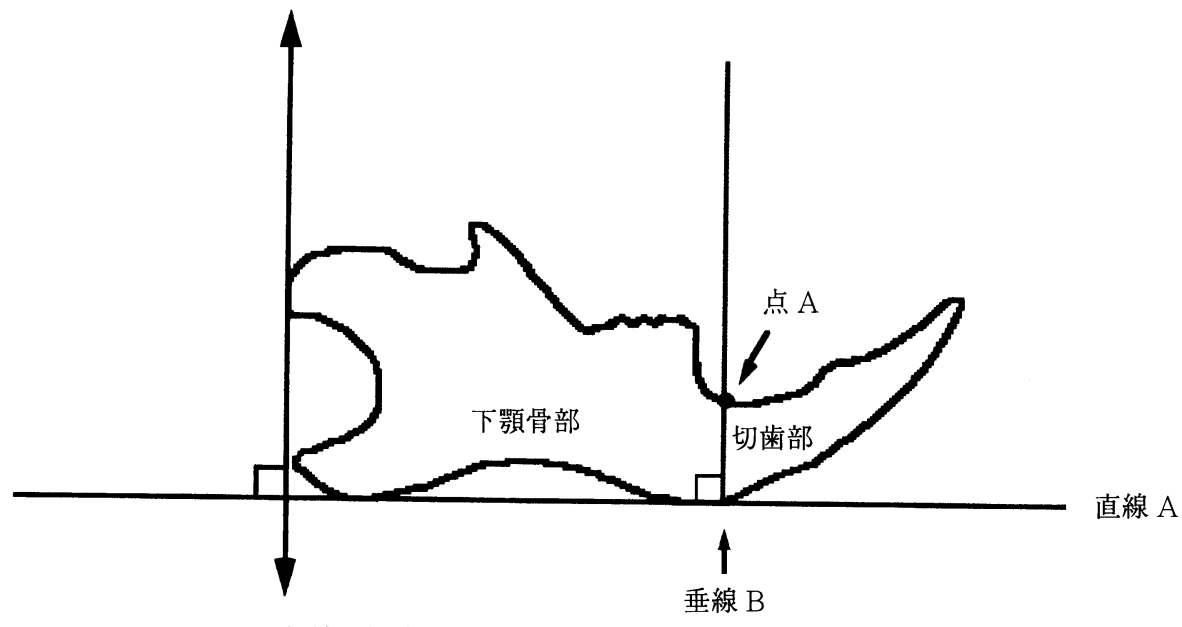

測定用放射線の経路

(Ultrahigh resolution mode)

図 2 DXA 法による下顎骨骨塩量の測定部位の設定

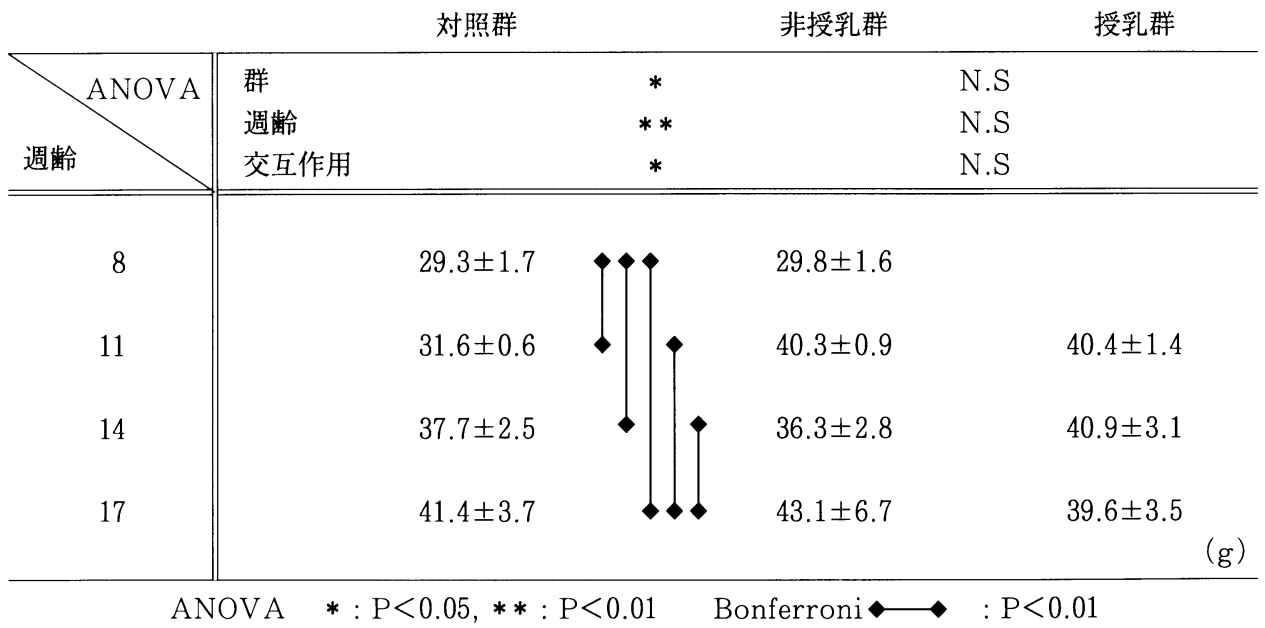

図 3 体重の推移

また，下顎切歯の影響を極力避けるために骨塩量の測 定部位を，切歯から兒歯へ移行する変曲点（点 A）を 通り直線 A と直交する垂線 (垂線 B) で切歯部と臼歯 および切歯歯根部を含む下顎骨部（以下，下顎骨部） に分け，下顎骨部の骨塩量を測定した（図 2 ). なお， マウス下顎骨部骨塩量の coefficient of variation 値

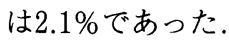

2 ) 下顎骨部面積 $(\mathrm{cm} 2)$ の測定

骨密度測定用のステントを使用して下顎骨の位置を 設定後，下顎骨を 2 倍の倍率で写真撮影を行った，画 像はコンピーター（power macintosh 8500/120) に 取り込んだ後, 画像解析ソフト (Ultimage: I\&I 社) を用いて先に設定した下顎骨部の面積を測定した. 


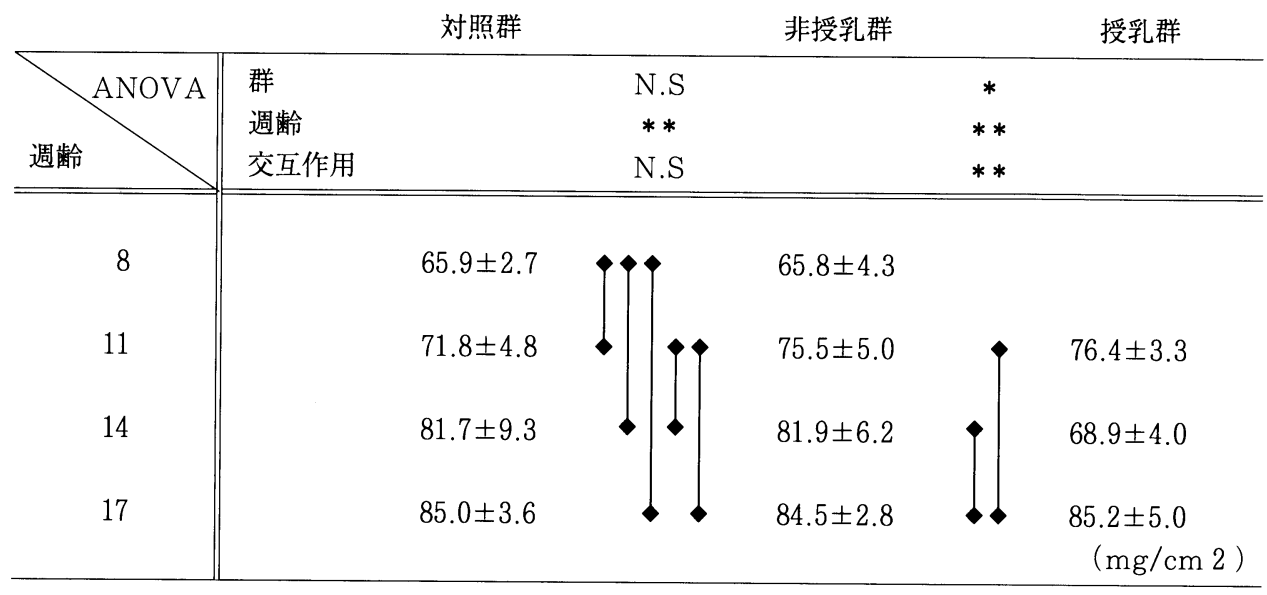

ANOVA $*: \mathrm{P}<0.05, * *: \mathrm{P}<0.01 \quad$ Bonferroni $\longleftrightarrow: \mathrm{P}<0.01$

図 4 下顎骨密度の推移

3 ) 下顎骨骨密度 (mgrams $/ \mathrm{cm} 2$ ) の計算

骨密度 (mgrams / cm 2) = 骨塩量 (mgrams) / 面積 $(\mathrm{cm} 2)$ より下顎骨部の骨密度を面積密度として 算出した。

\section{4. 下顎骨骨密度の統計解析}

骨密度については群と週歯を変動要因として 2 元配 置分散分析 (Factorial ANOVA) で解析を行った。 また群間，週齢間の比較には Bonferroni-testを用い た。

\section{結果}

\section{1. 体重}

1 ) 妊娠・出産による影響

対照群と非授乳群の体重の比較では, 群および週齢 による有意差を認め, さらに週歯と群による交互作用 を認めた。週齢間の比較では体重は経時的に増加した が, 11週齢から14週齢間では有意差を認めなかった。 これには出産直後である非授乳群の11週齢の体重が同 週齢の対照群の体重より重かったことが関与していた (図 3 ).

\section{2 ) 授乳による影響}

非授乳群と授乳群において, 出産直後からの体重の 比較を行ったところ有意差を認めなかった（図 3 ).

\section{2. 下顎骨部骨密度}

1) 妊娠・出産による影響

対照群と非授乳群の下顎骨密度の比較では, 下顎骨 密度は週齢による有意差を認めたが, 群による有意差 は認めなかった．また週齢と群による交互作用は認め
なかった. 週齢間の比較では骨密度は 8 週齢から 14 週 齢間に有意に増加した（図 4 ）。

\section{2 ) 授乳による影響}

授乳群と非授乳群において, 出産直後からの下顎骨 密度の比較を行ったところ, 骨密度は週歯および授乳 の有無による有意差を認めた.また週歯と授乳の有無 には交互作用を認めた。週齢間の比較から 11 週齢, 14 週齢より17週齢の骨密度は有意に増加したが，11週齢 と14週路間では有意差を認めなかった. 群間の比較で は14週歯の授乳群の骨密度は同週路の非授乳群の骨密 度より低下していたが, 17週齢では両群間に差を認め なかった（図4).

\section{考察}

妊娠・産裖期には胎盤や授乳を介して母体から胎児 ・ 新生児にかなりのカルシウムやリンが移行し $3,17,18)$, そのため母体ではカルシウムの補充機構が働くものの, なお骨密度や骨代謝への影響があるのではと考えられ ている ${ }^{3)}$. 近年, 妊娠 ・産裖期での骨密度の検討が匕 トでは主に超音波骨密度測定装置 ${ }^{1 \sim 3)}$, 動物では DXA 法を用いて 4,5$)$ 橈骨, 踵骨, 大腿骨, 腰椎で行 われてきた．これらの検討によると，妊娠後期では骨 密度はやや低下寸るとの報告 2,5$)$ がある一方で, 妊 娠中は無変化であるとする報告もある ${ }^{6 \sim 8)}$. しかし 授乳期では骨密度は低下するとの報告が多く3，5，19)， 授乳期間が長いほどこの傾向は強くなり ${ }^{20)}$, 断乳によ り次第に回復すると考えられている ${ }^{9,10)}$. しかし，こ れらの結果について, 特にヒトでは個々の食物摂取のば らつきの問題や妊娠 ・産裖期での身体活動の影響 2124$)$ 
が指摘されていたそそこでわれわれは DXA 法による マウスの骨密度の検討を行うにあたり, 食物摂取につ いては飭の種類は同一であり，身体活動の影響につい ては力学的影響の観点から体重の増加による持続的な 負荷や身体活動の違いの影響を受けにくいことや下顎 骨骨密度の検討がないことを考慮して，下顎骨を選択 した.さらに, 骨密度の測定範囲は, ラットでは完成 臼歯のミネラル代謝はほとんどないが切歯のそれは活 発 ${ }^{25)}$ であることを考慮し, 主に下顎骨骨密度の変化を 描出すべく測定範囲からマウスの切歯を可及的に除外 した，その結果から，マウス下顎骨骨密度は妊娠によ る影響は受けないこと, 授乳による影響は受けて授乳 時には下顎骨骨密度の増加は抑制され非授乳時より低 値を示すこと, 断乳後はすみやかに骨密度が回復する ことが判明した。

一方, 骨密度の変化には骨の代謝回転がその背景と して存在しており，骨代謝回転の検討が骨形態計測や 骨量に先行し，より鋭敏な骨代謝回転の指標である骨 代謝マーカーにより測定されてきた。 その結果, 妊娠 期や産裖期の骨代謝ではコントロール群との比較や授 乳の有無の比較で骨密度に差がみられない場合でも骨 代謝のレベルでは変化が生じている, または長期に継 続している可能性が指摘されており $2,3,11)$, 顎骨にお いてもさらに骨代謝レベルでの検討の余地があると考 えられる。

さらに, 授乳による骨吸収促進の要因では骨の吸収 に関係する副甲状腺ホルモンや吸収抑制に関係する工 ストロジェンなどのホルモンの検討から, 副甲状腺ホ ルモンの高值, 出産後のエストロジェン值の急激な低 下, 非授乳に比べて長い低エストロジェン状態の関与 が示唆されており, 母体のミネラル摂取量や濃度, 子 供への移行の問題も考えられている1 3, 11, 17, 18). こ のようなミネラルの問題については, 低 $\mathrm{Ca}$ 食給飭ラッ トの授乳期に発現する大腿骨骨密度の低下は, $\mathrm{Ca}$ の 補充で改善できるとする報告 ${ }^{4)}$ や, Ca 撕取の重要性 を説く報告 ${ }^{1)}$ がある. われわれの研究ではマウスの餌 は自由摂取 ${ }^{26,27)}$ であり，かつ下顎骨での検討にもか かわらず授乳によって正常な骨密度の増加が抑制され, 非授乳群に比べ低い骨密度值を示したことから，授乳 期では母マウスと仔マウス間でのミネラル移行量の不 均衡, 摂取ミネラル濃度やホルモン等の要因が関与し ているのではと考えられた。

\section{結}

\section{語}

妊娠および産裖期マウスを用いて，妊娠と授乳が下 顎骨骨密度に与える影響を DXA 法により検討し以下 の結果を得た。

1. 対照群と非授乳群間の骨密度の比較では, 両群 ともに骨密度は 8 週齢から14週㱓間に有意に増加した
が群による有意差は認めず, 妊娠・出産による骨密度 への影響は認めなかった。

2. 非授乳群と授乳群間では骨密度に有意差を認め た.この差は出産後 3 週間授乳させた 14 週齢の授乳群 の骨密度が同週齢の非授乳群に比べ低い結果によるも のであった。

3. 授乳による下顎骨骨密度の低值は断乳により速 やかに回復した。

\section{引用 文 献}

1）米山京子, 池田順子, 他：母乳中カルシウム濃 度と授乳婦の乳, 乳製品㠌取, 骨吸収および骨 密度との相互関係. 日衛誌 51: 770-779 1997.

2）真鍋麻美, 鍵谷昭文, 他 : 妊娠産裖期の骨代謝 について. 青森臨産婦医会誌 10: 37-43 1995.

3）水口弘司, 多賀理吉, 他 : 産裖期の骨 ・カルシ ウム代謝. Bone 18: 89-95 1994.

4）菊池武夫, 藤井祐二, 他：授乳期ラットにおけ る卵款カルシウムの骨塩量維持効果. 日栄 ·食 糧会誌 47: 11-14 1994.

5) Tojo, Y., Kurabayashi, T., et al.: Bone structural and metabolic changes at the end of pregnancy and lactation in rats. Am J Obstet Gynecol 178: 180-185 1998.

6）古謝将一郎, 永田行博 : 妊娠 - 産褯期の骨量の 変化. 臨婦産 48: 1086-1087 1994.

7) Sowers, M.F., Crutchfield, M., et al.: A prospective evaluation of bone mineral change in pregnancy. Obstet Gynecol 77: 841-845 1991.

8) Christiansen, C., R $\phi$ dbro, P., et al.: Unchanged total body calcium in nomal human pregnancy. Acta Obstet Gynecol Scand 55: 141-143 1976.

9) Sowers, M.F., Corton, G., et al.: Changes in bone density with lactation. JAMA 269: 3130-3135 1993.

10）浜本 保, 出田和久: 裖婦骨密度の測定一産後 の骨密度の推移と分婏間隔による変化. Osteoporosis Japan 2: 139-141 1994.

11）春名めぐみ, 福岡秀興：骨代謝マーカーによる 妊娠 - 産裖期の骨代謝動態に関する検討. 体力 研 91: 109-115 1996.

12）石田 悟：実験的骨粗珐症ラットにおける下顎 頭の変化に関する研究一大腿骨頭および脊椎骨 との比較一. 日口外誌 41: 957-969 1995.

13）小林 博：骨粗牃症が顎骨などにおよほす影響 についての実験的および臨床的研究. 歯科学報 92: 711-727 1992.

14）柴田直樹 : ラットの実験的根尖病変の形成にお よほす卵巣摘出骨粗街症の影響. 愛院大誌 34 : 159-179 1996.

15）佐藤真弥子, 角田左武郎, 他 : 閉経後の顎関節 
症患者における骨塩量と下顎頭の変形 (抄). 昭 和歯会誌 18: 107-108 1998.

16）高橋喜久彌, 三浦久幸, 中村 勝, 望月 博, 大 石勝也, 他 : DEXA 法による小動物モードの 基礎的研究. コニカ X-レイ写真研究 46: 6-9 1995.

17) Atkinson, P.J., West R.R.: Loss of skeltal calsium in lactating women. $\mathrm{J}$ Obstet Gynaecol British Commonwealth 77: 5555601970.

18) Lamke, B., Brundin, J., et al.: Changes of bone mineral content during pregnancy and lactation. Acta Obstet Gynecol Scand 56: 217-219 1977.

19) Hayship, C., Klein, T., et al.: The effect of lactation on bone mineral content in healthy postpartum women. Obstet Gynecol 73: 588-592 1989.

20) Wardraw, G.M., Pike, A.: The effect of lactation on peak adult shaft and ultradistal forearm bone mass in women. Am
J Clin Nutr 44: 283-286 1986.

21) Drinkwater, B.L., Chesnut, CH III .: Bone density changes during pregnancy and lactation in active women: a longitudinal study. Bone Miner 14: 153-160 1991.

22) Tylavsky, F.A., Curtis, C.: Changes in radial and vertebral bone mass due to pregnancy and lactation in humans. J Bone Miner Res S414 1989.

23) Brooks, G.G., Thomas, B.V., et al.: Hip pain in late pregnancy. $\mathrm{J}$ Reprod Med 35: 969-970 1990.

24）古謝将一郎, 児島信子, 永田行博 : 妊娠 · 産裖 婦人の骨量の推移一特に長期授乳の影響につい て. Bone 8: 97-104 1994.

25）茂田貫一：歯牙硬組織の代謝に関する研究. 科誌 8: 3921959 .

26）岡本 徹: 硬組織および血清中 $\mathrm{P}$ 量の妊娠に よる変動. 口科誌 23: $1-71974$.

27）滝川 尚：硬組織および血清中の $\mathrm{Ca}, \mathrm{Mg}$ 濃 度の妊娠による変動. 口科誌 22: 328-337 1973. 